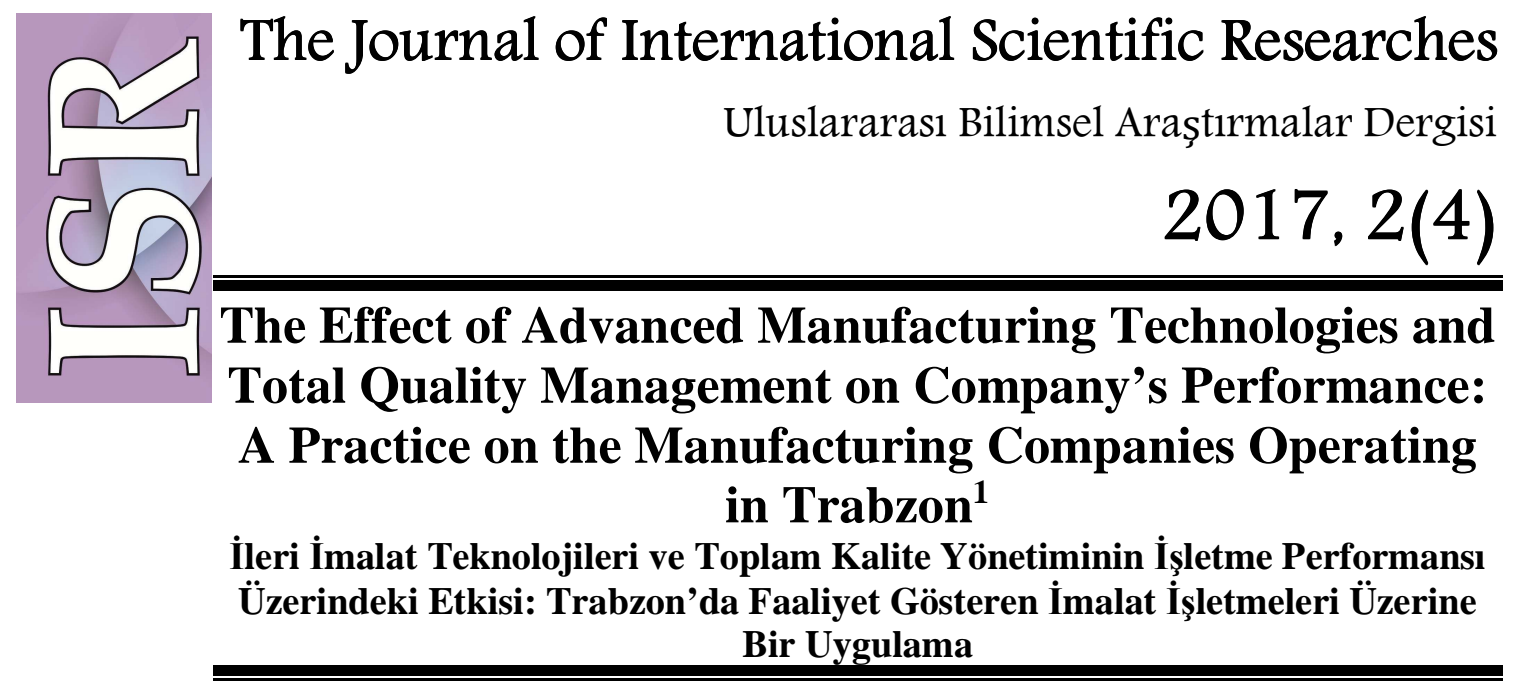

Büşra Tosunoğlu², Selim Cengiz ${ }^{3}$, Gülsüm Akelma ${ }^{4}$

\begin{abstract}
The objective of this study is to determine the effect of the advanced manufacturing technologies and total quality management on a company's performance. In accordance with this, a model has been developed and tested. Two hypotheses have been generated to test the model and a poll has been carried out on 140 firms operating in manufacturing industry in city of Trabzon. Structural equation model has been used to test the hypotheses generated. In accordance with the findings of the analysis it is determined that; total quality management has a high level and positive effect on company's performance; however advanced manufacturing technologies do not have any effect on company's performance.
\end{abstract}

Keywords: Advanced Manufacturing Technologies, Total Quality Management, Company's Performance, Structural Equation Model

ÖZ

Bu çalışmanın amact, ileri imalat teknolojileri ve toplam kalite yönetiminin işletme performansı üzerindeki etkisini belirlemektir. Bu doğrultuda bir model geliştirilmiş ve test edilmiştir. Modelin testi için iki hipotez oluşturulmuş ve Trabzon Illi imalat sektöründe faaliyet gösteren 140 firmaya bir anket uygulanmıştır. Oluşturulan hipotezlerin test edilmesinde yapısal eşitlik modeli kullanılmıştır. Analiz bulgularına göre; toplam kalite yönetiminin işletme performansı üzerinde yüksek düzeyde ve pozitif bir etkiye sahip olduğu; ileri imalat teknolojilerinin ise işletme performansi üzerinde herhangi bir etkiye sahip olmadiğ l sonucuna ulaşılmiştır.

Anahtar Kelimeler: İleri İmalat Teknolojileri, Toplam Kalite Yönetimi, İşletme Performansı, Yapısal Eşitlik Modeli

\footnotetext{
${ }^{1}$ Bu makale, 12-14 Ekim tarihlerinde Bilecik te yapılan Uluslararası Osmaneli Sosyal Bilimler Kongresinde bildiri olarak sunulmuştur.

${ }^{2}$ Yrd.Doç.Dr., Gümüşhane Üniversitesi, İ̈BF, İşletme Bölümü

${ }^{3}$ Yrd.Doç.Dr., Çankırı Karatekin Üniversitesi, İİBF, İşletme Bölümü

${ }^{4}$ Gümüşhane Üniversitesi, Sosyal Bilimler Enstitüsü
} 
INTRODUCTION

Rapidly changing competition and market conditions in an environment of uncertainty cause a new competitive environment for companies (Bayus, 1994). This change experienced necessitates for manufacturing companies to make some alteration within their manufacturing systems in order to produce high quality products and meet the customer demands rapidly (Roth, 1996).

The companies tend towards improving their manufacturing processes in order to maintain the sustainability against their competitors within this rapidly developing and growing market and towards using appropriate technologies for themselves in order to high quality and demand suitable manufacturing at a low cost level. In this sense, Advanced Manufacturing Technologies (AMT), which gained worldwide acceptance, have started to take part in the manufacturing companies and therefore have brought in to the literature and become widespread in companies' practices at the end of 1980's (Patterson et al., 2004). With AMT, the companies tend towards technology for product and process design, production planning and control, manufacturing process and combining all of these activities. Moreover AMT, provide the opportunity for the rapid development and manufacturing high quality products with lower costs (Rahardjo and Yahya, 2010). Despite the benefits of the advanced manufacturing technologies stated above, since these technologies have high costs and complicated structures, the difficulties that may be experienced during the usage of these technologies and lack of sufficient experts, it is observed that the companies behave timidly at the stage of practicing these technologies (Ünğan et al., 2015).

Total Quality Management (TQM), is defined as a product-service and process oriented management philosophy, in accordance with the customer needs and expectations in order to company's performance and customer satisfaction (Kaynak, 2003). In parallel with positive impacts of TQM on customer satisfaction, motivation, efficiency and quality, it also enables company's performance to maximize.

When the literature concerning the effects of advanced manufacturing technologies and total quality management on the company's performance is examined, it is possible to see many studies conducted on this topic. Aforementioned studies will be mentioned in the literature research section. When related literature is examined, it is determined that advanced manufacturing technologies are highly important for the manufacturing companies, however, it is also determined that the manufacturing companies behave timidly at the point of using these technologies. Based on this situation, the objective of this study is to determine the effects of AMT and TQM on the performance of manufacturing companies, which operate in city of Trabzon.

On the study related literature has been included with priority in order to constitute a conceptual framework. Thereafter, the model of the study has been constituted and the hypotheses obtained from the model have been examined.

\section{LITERATURE RESEARCH}

In this section, which aims to give place to the studies concerning the effects of the advanced manufacturing technologies and total quality management on the companies' performances, the related literature has been examined under two titles being "the effect of advanced manufacturing technologies on company's performance" and "the effect of total quality management on company's performance."

1.1. The Literature Concerning the Effect of Advanced Manufacturing Technologies on Company's Performance

When the studies conducted on the effects of the advanced manufacturing technologies on company's performance examined generally, it is observed that advanced manufacturing technologies provide various contribution to the companies such as flexibility, delivery on time and producing high quality products etc. (Kotha 
and Swamidass, 2000). Furthermore, advanced manufacturing technologies enable companies to play an active role under the conditions of competition by increasing their production efficiency (Dean and Snell, 1996; Swamidass and Kotha, 1998). In contrast to the positive impacts of advanced manufacturing technologies on the companies' performance, there are also some studies stating that aforementioned technologies do not have any effect on the company's performance. In accordance with Boyer et al. (1996); Beaumont and Schroder (1997) and Cagliano and Spina (2000), advanced manufacturing technologies do not have any effect on company's performance. The summary of the literature, which was stated in general above, is presented on the Table 1.

Table 1: Literature Concerning the Effect of Advanced Manufacturing Technologies on the Company's Performance

\begin{tabular}{|c|c|c|c|}
\hline $\begin{array}{c}\text { Writers/ Year of } \\
\text { the Study }\end{array}$ & Sample & Method & Results of the Study \\
\hline Boyer et al. (1996) & Metal Industry & $\begin{array}{l}\text { Cluster } \\
\text { Analysis }\end{array}$ & $\begin{array}{l}\text { There isn't any difference between } \\
\text { companies that use advanced } \\
\text { technologies and companies that do } \\
\text { not use advanced manufacturing } \\
\text { technologies concerning their } \\
\text { performances. }\end{array}$ \\
\hline $\begin{array}{l}\text { Beaumont and } \\
\text { Schroder (1997) }\end{array}$ & $\begin{array}{c}\text { Manufacturing } \\
\text { Companies }\end{array}$ & $\begin{array}{c}\text { Mean- } \\
\text { Whitney Test }\end{array}$ & $\begin{array}{l}\text { There isn't any relationship between } \\
\text { advanced manufacturing } \\
\text { technologies and company's } \\
\text { performance. }\end{array}$ \\
\hline $\begin{array}{c}\text { Kotha and } \\
\text { Swamidass (2000) }\end{array}$ & $\begin{array}{c}\text { Manufacturing } \\
\text { Companies }\end{array}$ & Regression & $\begin{array}{l}\text { Advanced manufacturing } \\
\text { technologies provide information } \\
\text { exchange, planning and product } \\
\text { design and also offer the companies } \\
\text { to benefit from low scale flexible } \\
\text { automation technologies. }\end{array}$ \\
\hline $\begin{array}{c}\text { Cagliano and Spina } \\
(2000)\end{array}$ & Metal Industry & Fuzzy Logic & $\begin{array}{l}\text { There isn't any difference between } \\
\text { the performances of companies that } \\
\text { use advanced manufacturing } \\
\text { technologies and companies that do } \\
\text { not use these technologies. }\end{array}$ \\
\hline
\end{tabular}

\subsection{The Literature Concerning the Effect of Total Quality Management on Company's Performance}

When the studies conducted on the effects of the total quality management on company's performance examined generally, it is observed that TQM practices have positive impacts on efficiency and production performance (Chenhall, 1997), quality (Prajogo and Hong, 2008; Lee et al., 2003) employee and customer satisfaction (Fuentes et al., 2006) and total company performance (Dougles and Judge Jr., 2000; Cerio, 2003; Çetindere et al., 2015). The summary of the literature, which was stated in general above, is presented on the Table 2. 


\begin{tabular}{|c|c|c|c|}
\hline $\begin{array}{l}\text { Writers/ Year of } \\
\text { the Study }\end{array}$ & Sample & Method & Results of the Study \\
\hline $\begin{array}{l}\text { Prajogo and Hong } \\
\text { (2008) }\end{array}$ & $\begin{array}{c}\text { Manufacturing } \\
\text { Companies }\end{array}$ & $\begin{array}{l}\text { Structural } \\
\text { Equation } \\
\text { Model } \\
\end{array}$ & $\begin{array}{l}\text { Total quality management has a } \\
\text { meaningful effect on the company's } \\
\text { performance. }\end{array}$ \\
\hline Chenhall (1997) & $\begin{array}{l}\text { Manufacturing } \\
\text { Companies }\end{array}$ & Regression & $\begin{array}{l}\text { Companies with high performances } \\
\text { attach more importance to the total } \\
\text { quality management, in other words } \\
\text { there is a strong trust connection } \\
\text { between performance and total } \\
\text { quality management. }\end{array}$ \\
\hline $\begin{array}{l}\text { Douglas and Judge } \\
\qquad(2000)\end{array}$ & Hospitals & Anova & $\begin{array}{l}\text { Total quality management } \\
\text { contributes companies to gain } \\
\text { competitive advantage. }\end{array}$ \\
\hline Lee et al. (2003) & $\begin{array}{l}\text { Manufacturing } \\
\text { Companies }\end{array}$ & $\begin{array}{l}\text { Structural } \\
\text { Equation } \\
\text { Model }\end{array}$ & $\begin{array}{l}\text { Effective management of the quality } \\
\text { is quite effective on the company's } \\
\text { performance. }\end{array}$ \\
\hline Cerio (2003) & $\begin{array}{l}\text { Electric, } \\
\text { Water and } \\
\text { Mining } \\
\text { Companies }\end{array}$ & $\begin{array}{l}\text { Multiple } \\
\text { Regression } \\
\text { Analysis }\end{array}$ & $\begin{array}{l}\text { Total quality management is } \\
\text { important for the companies in terms } \\
\text { of low cost, high quality products and } \\
\text { flexible production. }\end{array}$ \\
\hline Fuentes (2006) & $\begin{array}{l}\text { Private } \\
\text { Companies }\end{array}$ & Anova & $\begin{array}{l}\text { As much the conformity between the } \\
\text { strategic structure of the companies } \\
\text { and the total quality management, } \\
\text { they are as much advantageous with } \\
\text { regards to performance. }\end{array}$ \\
\hline $\begin{array}{c}\text { Çetindere et al. } \\
\text { (2015) }\end{array}$ & $\begin{array}{l}\text { Kütahya } \\
\text { Organized } \\
\text { Industry }\end{array}$ & $\begin{array}{c}\text { Regression - } \\
\text { Correlation }\end{array}$ & $\begin{array}{l}\text { There is a strong relationship } \\
\text { between total quality management } \\
\text { and company's performance. The } \\
\text { high performance of the companies is } \\
\text { connected to the efficient use of total } \\
\text { quality criteria. }\end{array}$ \\
\hline
\end{tabular}

\section{THE OBJECTIVE, METHODOLOGY AND FINDINGS OF THE RESEARCH}

\subsection{The Objective of the Study}

The objective of the study is to determine the effects of the advanced manufacturing technologies and total quality management of the companies' performances.

\subsection{Methodology of the Study}

\subsubsection{Sample Process}

The research universe contains the manufacturing companies operating in the city of Trabzon. Convenience sampling method was used in determination of the sample mass. The sample size of a universe consisting of 1000 people in accordance with the $95 \%$ confidence interval range and with $e=5 \%$ margin of error has to be 278 (Kurtuluş, 1998). There are 500 manufacturing companies operating actively in the city of Trabzon. In the research, 140 of the surveys conducted on the manufacturing companies operating in the city of Trabzon were taken into consideration. The features of the companies, which participated in the research, regarding the sectorial structures are presented on Table 3. 


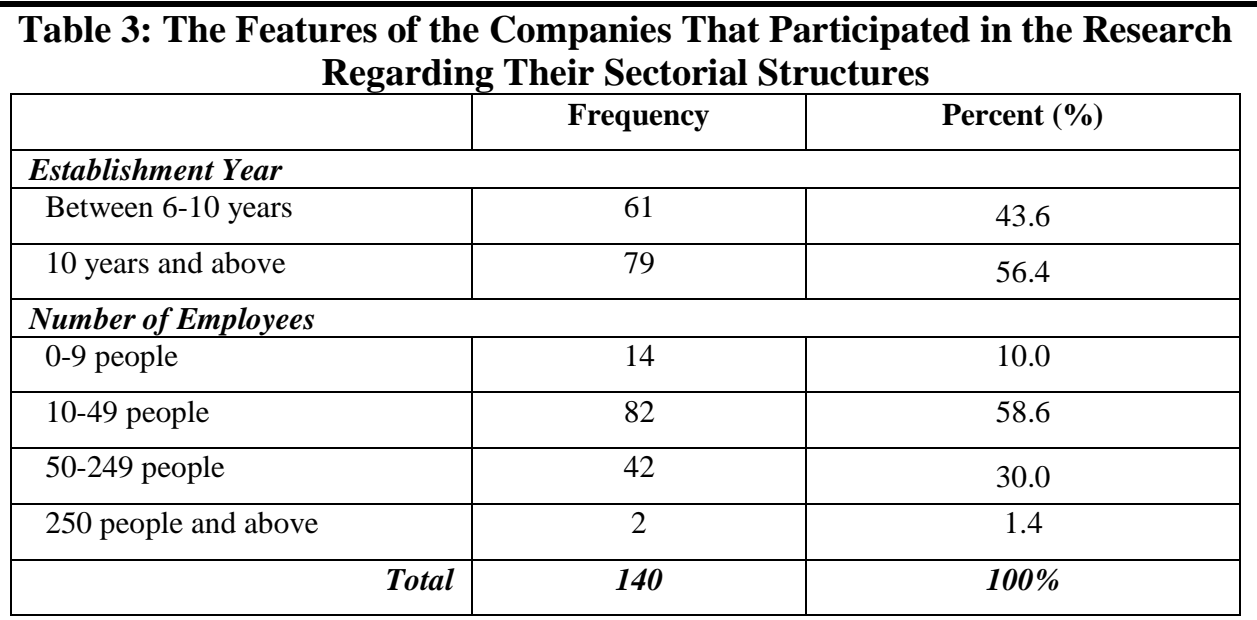

When the distribution of the companies, which participated in the research, regarding their establishment years, it is observed that $43.6 \%$ of the companies (61 companies) establishment year is between 6-10 years and $56.4 \%$ of the companies (79 companies) establishment year is 10 years and above. When the employee number of the companies, which participated in the research, it is observed that 10 $\%$ of the companies' (14 companies) employee number is between 0-9 people, 58.6 $\%$ of the companies' (82 companies) employee number is between $10-49$ people, 30 $\%$ of the companies' (42 companies) employee number is between 50-249 and 1.4 $\%$ of the companies' employee number is 250 people or more.

When a general evaluation of the companies, which participated in the research, regarding the industry they operate in it is observed that $60.7 \%$ of the companies operate in food and drink industry, $11.4 \%$ of the companies operate in wood and forestry products industry, $6.4 \%$ of the companies operate in glass-ceramics industry, $6.4 \%$ of the companies operate in metal industry, $2.1 \%$ of the companies operate in water products industry, $2.9 \%$ of the packing industry, $5 \%$ of the building materials industry, $1.4 \%$ of the companies operate in textile-ready wear industry and $3.6 \%$ of the companies operate in other industries. Most of the companies operating in city of Trabzon, which offer various opportunities to both national and international investors, operates in "food and drinks" industry that also comprise the hazelnut and tea subtitles.

\subsubsection{Data Collection Methodology and Tool}

In the study, during the data collection stage, a survey method is used and applied to the manufacturing companies operating in city of Trabzon. The survey form was applied both via face to face interviews conducted with companies' officials and also by reaching them via telephone and e-mail.

The questions on the first part of the research consist of the questions aimed at determining the sectorial structures of the companies. The second part consists of the questions regarding the effects of the advanced manufacturing technologies and total quality management of the companies' performance. 5 Point Likert scale (5: I Strongly Agree, 4: I Strongly Agree, 3: Neutral, 2: I Disagree and 1: I Strongly Disagree) was used on the survey and the participants were asked to answer to each question asked in accordance with their situation. The survey questions were conducted benefitting from the studies of Challis et al. (2002).

\subsubsection{The Model and the Variables of the Research}

The hypotheses developed in order to determine the effects of advanced manufacturing technologies and total quality management on companies' performance is presented below:

Kotha and Swamidass (2000), Dean and Snell (1996) and Swamidass and Kotha (1998) have stated that advanced manufacturing technologies have a positive impact on the company's performance. Based on this point of view, the hypothesis stated below was developed; 
$\mathbf{H}_{1}$ : Advanced manufacturing technologies have a positive effect on the company's performance.

Douglas and Judge (2000), Sharma (2006), Cerio (2003) and Çetindere et al. (2015) have stated that total quality management has a positive effect on company's performance. Based on this point of view, the hypothesis stated below was developed;

$\mathbf{H}_{2}$ : Total quality management has a positive effect on the company's performance.

Based on the hypotheses mentioned above the model presented below was developed;

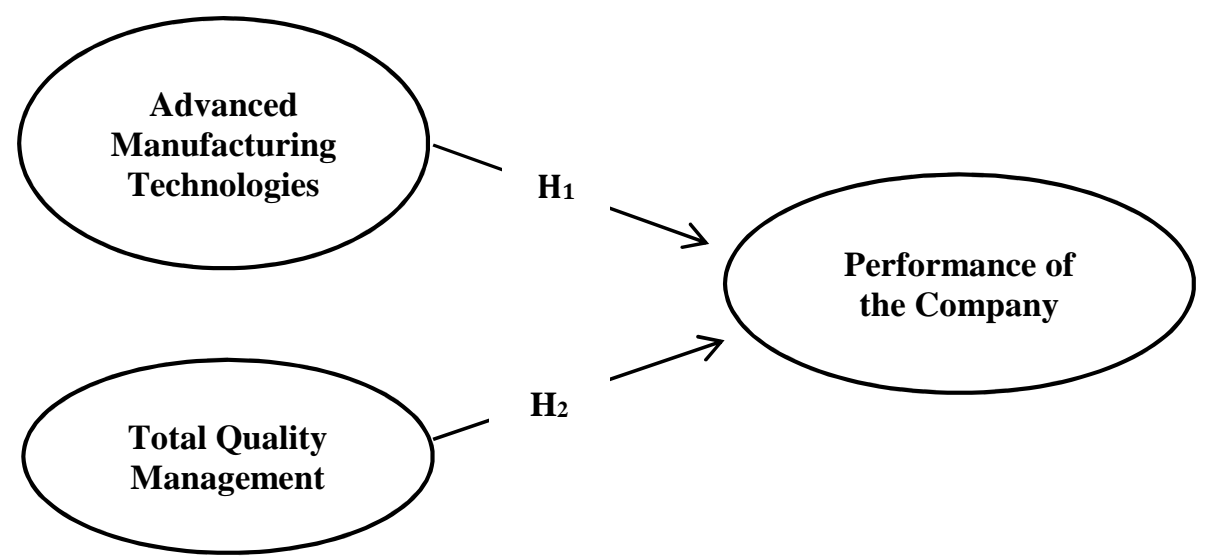

Figure 1: The Model of the Research

\subsubsection{The Analysis Method of the Research}

In the analysis of this research, where the effects of advanced manufacturing technologies and total quality management on the companies' performance, Structural Equation Model (SEM), which handles the relationship between the dependent and independent variables within a single process and which is defined as the second generation data analysis technique, was used (Anderson and Gerbing W., 1998). SPSS 21.0 and AMOS 20.0 package program were used in all the analysis conducted.

\subsection{The Findings of the Research}

\subsubsection{Measuring Model}

In this research, reliability analysis and exploratory factor analysis were conducted intended for examination of the factors used. The results of exploratory factor analysis and reliability analysis concerning the variables taking part in the model are presented on Table 4. 
Table 4: The Results of the Sample's Exploratory Factor Analysis and Reliability Analysis

\begin{tabular}{|c|c|c|c|}
\hline Scale Items & CP1 & TQM $^{2}$ & AMT3 $^{3}$ \\
\hline $\begin{array}{l}\text { S1. We have highly motivated employees. } \\
\text { S2. Our employees operate with high efficiency. } \\
\text { S3. We have less waste of time in industrial conflicts considered to other } \\
\text { companies. } \\
\text { S4. We are advantageous regarding the skills and abilities of the } \\
\text { employees. } \\
\text { S5. The internal customer concept is clearly understood in our company. } \\
\text { S6. We have a very high level of customer satisfaction. } \\
\text { S7. We have a quite positive cash flow. } \\
\text { S8. The total cost per unit of our products is much lower than our } \\
\text { competitors'. } \\
\text { S9. We deliver the products to our customers on time. } \\
\text { S10. Total quality management contributes to the competitive position. } \\
\text { S11. Quality is under responsibility of all of our employees. } \\
\text { S12. We have sufficient methods to measure the quality of the goods and } \\
\text { services. } \\
\text { S13. We are continuously pursuing the developments in reaction to crisis. } \\
\text { S14. We know the current and future requirements of our foreign } \\
\text { customers. } \\
\text { S15. The needs of our customers are well understood by our labor force. } \\
\text { S16. We have the efficient process to solve the complaints of our } \\
\text { customers. } \\
\text { S17. Statistical process control helps our company. } \\
\text { S18. The computer supported design contributes in the competitive } \\
\text { position. } \\
\text { S19. The computer supported numerical controlled machines contribute } \\
\text { in the competitive position. } \\
\text { S20. Flexible production units and systems contribute in competitive } \\
\text { position. }\end{array}$ & $\begin{array}{l}0.863 \\
0.875 \\
0.730 \\
0.870 \\
0.776 \\
0.781 \\
0.742 \\
0.598 \\
0.611\end{array}$ & $\begin{array}{l}0.750 \\
0.678 \\
0.710 \\
0.715 \\
0.821 \\
0.888 \\
0.820 \\
0.781\end{array}$ & $\begin{array}{l}0.848 \\
0.901 \\
0.729\end{array}$ \\
\hline Explained Variance (\%) & 29.708 & 23.242 & 19.652 \\
\hline Explained Total Variance (\%) & \multicolumn{3}{|c|}{72.602} \\
\hline Kaiser-Meyer-Olkin (KMO) Test & \multicolumn{3}{|c|}{0.880} \\
\hline Barlett's Test of Sphericity & \multicolumn{3}{|c|}{$\begin{array}{l}\chi 2=2321.576 ; \text { df: } 190 \\
(\mathrm{P}<000)\end{array}$} \\
\hline Cronbach's Alpha (\%) & \multicolumn{3}{|c|}{0.94} \\
\hline
\end{tabular}

As a result of the exploratory factor analysis, 4 (S21, S22, S23 and S24) statements are removed from the scale since they are loaded to more than one factor. In accordance with the results of the scale's exploratory factor analysis stated in Table 4, a model with 3 factors was obtained that explains the $72.60 \%$ of the total variance. The factors consist of company performance comprising 9 statements, total quality management comprising 8 statements and advanced manufacturing technologies comprising 3 factors. The suitability of the data to the factor analysis may be explained with Kaiser-Mayer-Olkin (KMO) and Bartlett test and it is also stated that the minimum value for KMO has to be 0.50 (Field, 2000). When the table above is taken into consideration, it is seen that KMO value is 0.88 . Bartlett's test result is $\mathrm{p}<, 000$ and it can be stated that the scale is applicable for the factor analysis. Finally, when reliability analysis results are examined, the general Cronbach's Alpha coefficient of the scale is calculated as $94 \%$.

\subsubsection{The Results of the Structural Equation Model}

In the structural equation model, the evaluations to determine whether the model should be approved or declined are done via goodness of fit indexes (Information Technology Services, 2004).

The results of the evaluation made by taking the goodness of fit indexes are presented on Table 5.

\footnotetext{
${ }^{1}$ Company Performance

2 Total Quality Management

${ }^{3}$ Advanced Manufacturing Technologies
} 


\begin{tabular}{|l|r|}
\hline \multicolumn{1}{|c|}{ Table 5: The Results of the Goodness of Fit Research Model } \\
\begin{tabular}{|l|r|}
\hline \multicolumn{1}{|c|}{ Model Goodness of Fit Indexes } & \multicolumn{1}{|c|}{ Model } \\
\hline$\chi^{2}$ (Ki-Square) value & 350.160 \\
df (Degree of Freedom) & 152 \\
$\chi 2$ /df (Adjusted Ki-Square) & 2.304 \\
GFI (Goodness of Fit Index) & 0.811 \\
IFI (Incremental Goodness of Fit Index) & 0.914 \\
CFI (Comparative Goodness of Fit Index) & 0.912 \\
TLI (Tucker Levis Index) & 0.891 \\
RMSEA (Root Mean Square of Approximation of Error) & 0.097 \\
\hline
\end{tabular}
\end{tabular}

Ki-Square $(\chi 2)$ value was found high and meaningful. $(\chi 2=350,160$, df-degree of freedom=152). $\chi 2$ ddf value is calculated to be 2.304 and the fact that this value is below 3 is quite decent. The GFI, IFI, CFI and TLI values are calculated respectively as $0.811,0.914,0.912$ and 0.891 . Since aforementioned values are above 0.90 it means that the model is decent. When Table 5 is taken into consideration, it is observed that the model is close to acceptable although GFI and TLI values are below acceptable levels.

In Table 6, whether the relationships of the values to be used in evaluation of the standard loads and the hypotheses are meaningful or not is taken into consideration. During this evaluation, $\mathrm{p}$ values that are revealed by the values obtained from the AMOS program is utilized and the $p<0.05$ meaning level is used as a base.

Table 6: Test Results of Hypothesis of the Research Model

\begin{tabular}{|l|c|c|c|c|c|}
\hline $\begin{array}{c}\text { Structural } \\
\text { Relationships of } \\
\text { the Model }\end{array}$ & $\begin{array}{c}\text { Standard } \\
\text { (Regression)Loads }\end{array}$ & $\begin{array}{c}\text { Standart } \\
\text { Error }\end{array}$ & $\begin{array}{c}\text { Critical } \\
\text { Values }\end{array}$ & P Values & $\begin{array}{c}\text { Hypothesis } \\
\text { Result }\end{array}$ \\
\hline \multicolumn{7}{|l|}{ The Variables Effecting Company's Performance } \\
\hline $\mathrm{H}_{1}:$ AMT-CP & 0.010 & 0.061 & 0.172 & 0.863 & REJECTED \\
\hline $\mathrm{H}_{2}:$ TQM-CP & 0.902 & 0.127 & 8.162 & 0.000 & ACCEPT \\
\hline
\end{tabular}

(AMT: Advanced Manufacturing Technologies, CP: Company Performance, TQM: Total Quality Management)

$\mathrm{H}_{1}$ hypothesis was rejected with 0.010 regression coefficient and $\mathrm{p}=0.863$ value. This means that advanced manufacturing technologies have no effect on the company's performance. $\mathrm{H}_{2}$ hypothesis was accepted with 0.902 regression coefficient and $\mathrm{p}=0.000$ value. This means that total quality management effects the company's performance positively.

\section{CONCLUSION}

The ability of the companies to operate efficiently in modern days' competition conditions is connected to their pursuing the technological novelties. Two of these novelties are advanced manufacturing technologies and total quality management. In accordance with this, the objective of this study is to determine the effect of advanced manufacturing technologies and total quality management on the company's performance. In accordance with the results of $\mathrm{H}_{1}$ hypothesis is rejected. This means that the advanced manufacturing technologies do not have any effect on the company's performance. The results of the research show similarities between the results of the studies conducted by Boyer et al. (1996), Beaumont and Schroder (1007) and Cagliano and Spina (2000). On the other hand $\mathrm{H}_{2}$ hypothesis is accepted. This means that the total quality management effects the company's performance positively. The results of the research show similarities Cerio (2003), Douglas and Judge (2000) and Çetindere et al. (2015).

The findings of this study, total quality management effects company's performance positively. However companies do not prefer to use advanced manufacturing technology due to high cost and team of experts employment. Therefore the results of the study seem to support this finding. 
This research is only applied to companies operating in City of Trabzon. Whether these findings are true for companies operating in other cities can be found when the findings of research done about the aforementioned companies are compared.

\section{REFERENCES}

Anderson, J., C. and Gerbing, D., W. (1988). Structural equation modeling in practice: a review and recommended two-step approach. Psychological Bulletin, 103.

Bayus, B., L. (1994). Are product life cycles really getting shorter? Journal of Product Innovation Management, 11 (4), 300-308.

Beaumont, N., B. and Schroder, R., M. (1997). Technology, manufacturing performance and business performance amongst australian manufacturers. Technovation, 17 (6), 297-307.

Boyer, K., K., Ward, P., T. and Leong, G.,K. (1996). Approaches to the factory of the future. an empirical taxonomy. Journal of Operations Managemet, 14(4), 297-313.

Cagliano, R. and Spina, G. (2000). Advanced manufacturing techologies and strategicall flexible production. Journal of Operations Management, 18,169190.

Challis, D., Samson, D. and Lawson, B. (2002). Integrated manufacturing, employee and business performance: Australian and New Zealand. International Journal of Production Research, 40 (8), 1941-1964.

Chenhall, R., H. (1997). Reliance on manufacturing performance measures, total quality management and organizational performance. Management Accounting Research, 8 (2), 187-206.

Cerio, J., M. (2003). Quality management practices and operational performance: empirical evidence for spanish industry. International Journal of Production Research, 41 (12), 2763-2786.

Çetindere, A., Duran, C. and Yetişen, M., S. (2015). The effects of total quality management on the business performance: an application in the province of Kütahya. Procedia Economics and Finance, 23, 1376-1382.

Dean, J., W. and Snell, S., A. (1996). The strategic use of integrated manufacturing: an empirical examination. Strategic Management Journal, 17 (6), 459-480.

Douglas, T., J. and Judge Jr, W., Q. (2000). Total quality management implementation and competitive advantage: the role of structural control and exploration. Academy of Management Journal, 44 (1), 158-169.

Field, A., P. (2000). Discovering statistics using spss for windows, Sage publications, London.

Fuentes, M., M., F., Montes, F., J., L. and Fernandez, L., M., M. (2006). Total quality management, strategic orientation and organizational performance: the case of Spanish companies. Total Quality Management and Business Excellence, 17 (3), 303-323.

Information Technology Services (2004). Structural equation modeling using AMOS: An Introduction. http://www.utexas.edu/its/rc/tutorials/stat/amos/.

Kaynak, H. (2003). The relationship between total quality management practices and their effects on firm performance. Journal of Operations Management, 21, 405.

Kurtuluş, K. (1998). Pazarlama Araştırmaları. Avcıol Basın Yayın, İstanbul.

Kotha, S. and Swamidass, P., M. (2000). Strategy, advanced manufacturing technology and performance: empirical evidence from U.S. manufacturing firms. Journal of Operations Management, 18, 257-277.

Lee, S., M., Rho, B., H. and Lee, S., G. (2003). Impact of malcolm baldrige national quality award criteria on organizational quality performance. International Journal of Production Research, 41 (9), 2003-2020. 
Patterson, M. G., West, M., A. and Wall, T., D. (2004). Integrated manufacturing, emporwerment and company performance. Journal of Organizational Behavior, $25,649$.

Prajogo, D., I. and Hong, S., W. (2008). The effect of tqm on performance in r\&d environments: a perspective from South Korean firms. Technovation, 28 (12), 855-863.

Rahardjo, J. and Yahya, S., B. (2010). Advanced manufacturing technology implementation process in sme: critical success factors. Jurnal Teknik Industri, $12(2), 101$.

Roth, A., V. (1996). Achieving strategic agility through economies of knowledge. Strategy and Leadership 24 (2), 30-36.

Sharma, B. (2006). Quality management dimensions, contextual factors and performance: an empirical investigation. Total Quality Management and Business Excellence, 17 (9), 1231-1244.

Swamidas, P., M. and Kotha, S. (1998). Explaining manufacturing technology use, firm size and performance using a multidimensional view of technology. Journal of Operations Management, 17, 23-37.

Ünğan, M.,C., Demirkol, İ. and Üstündağ, A. (2015). İleri imalat teknolojileri ve bir saha çalışması. Kastamonu Üniversitesi İktisadi ve İdari Bilimler Fakültesi Dergisi, 6,77. 